\title{
MENELUSURI IDENTITAS IKAN LELE DUMBO
}

\author{
Bambang Iswanto \\ Balai Penelitian Pemuliaan Ikan \\ Jl. Raya 2 Sukamandi, Subang, Jawa Barat 41263 \\ E-mail: bambang.is031@kkp.go.id
}

\begin{abstract}
ABSTRAK
Lele dumbo merupakan salah satu ikan lele unggul yang budidayanya pernah mengalami perkembangan pesat di Indonesia. Secara umum, ikan lele dumbo dipercaya sebagai ikan lele hibrida hasil hibridisasi antara spesies ikan lele Afrika Clarias gariepinus dengan spesies ikan lele Taiwan C. fuscus. Tetapi, secara morfologis tampaknya ikan lele dumbo tidak berbeda dari strain-strain ikan lele Afrika $C$. gariepinus yang berikutnya diintroduksi ke Indonesia, sehingga para praktisi perikanan juga menduga bahwa ikan lele dumbo sebenarnya merupakan spesies ikan lele Afrika C. gariepinus. Dengan demikian, identitas ikan lele dumbo tetaplah belum jelas. Hal tersebut dikarenakan belum adanya penelitian yang mengeksplorasi karakteristik ikan lele dumbo secara ilmiah. Makalah ini merupakan ulasan penelusuran identitas ikan lele dumbo berdasarkan publikasi-publikasi yang relevan. Berdasarkan tinjauan terhadap beberapa bukti publikasi dalam ulasan ini, terindikasi bahwa ikan lele dumbo bukanlah ikan lele hibrida hasil hibridisasi antara ikan lele $C$. gariepinus dengan $C$. fuscus, tetapi tampaknya lebih merupakan spesies ikan lele Afrika C. gariepinus. Namun demikian, hal tersebut masih merupakan suatu indikasi, sehingga diperlukan penelitian-penelitian lebih lanjut untuk memastikan hal tersebut.
\end{abstract}

KATA KUNCI : identitas, lele dumbo, hibrida, Clarias gariepinus, Clarias fuscus

\section{PENDAHULUAN}

Ikan lele merupakan salah satu komoditas perikanan yang pengembangannya diminati oleh para pembudidaya di Indonesia. Hingga saat ini, Indonesia memiliki 16 spesies ikan lele lokal yang telah diidentifikasi (direview oleh Ferraris, 2007; Ng \& Hadiaty, 2011). Di antara spesiesspesies ikan lele lokal Indonesia tersebut, Clarias batrachus merupakan spesies yang telah lama berhasil dibudidayakan (Zonneveld et al., 1988; Knud-Hansen et al., 1990), diikuti oleh C. meladerma (Sudarto, 1993). Namun demikian, secara umum spesies-spesies ikan lele lokal memiliki laju pertumbuhan yang rendah dan tidak toleran terhadap patogen, sehingga budidayanya tidak berkembang (Van Weerd, 1995; Lenormand et al., 1998). Budidaya ikan lele di Indonesia mengalami perkembangan pesat setelah dilakukannya introduksi ikan lele unggul dari Taiwan yang dengan cepat berkembang dan populer di kalangan pembudidaya dengan nama ikan lele dumbo. Nama tersebut diberikan karena ikan lele introduksi tersebut memiliki laju pertumbuhan yang tinggi dan dapat mencapai ukuran yang besar. Kata "Dumbo" berasal dari kata "Jumbo" yang berarti berukuran besar, sedangkan kata "Dumbo" sendiri berarti gajah yang juga berarti berukuran besar (Mahyudin, 2008; Suyanto, 2008).

Perkembangan budidaya ikan lele dumbo yang pesat tersebut tidak diiringi dengan manajemen induk yang tepat sehingga kemudian mengalami penurunan mutu genetis. Upaya pemuliaan ikan lele dumbo telah berhasil dilakukan dengan dihasilkannya strain ikan lele sangkuriang yang dirilis berdasarkan Surat Keputusan Menteri Kelautan dan Perikanan Nomor 26/MEN/2004. Berdasarkan silsilahnya yang diperoleh melalui proses persilangan balik (backcross) di antara induk ikan lele dumbo generasi-generasi awal (di-review oleh Sunarma, 2004), ikan lele strain sangkuriang tersebut pada dasarnya adalah tetap ikan lele dumbo.

Dibalik kesuksesan perkembangan budidaya ikan lele dumbo, terdapat suatu permasalahan tentang ketidakjelasan identitasnya. Ketidakjelasan identitas ikan-ikan introduksi merupakan hal yang sering terjadi. Hal tersebut dikarenakan 
hampir selalu tidak pernah adanya laporan atau publikasi ilmiah yang mendokumentasikannya, sehingga publikasipublikasi populer (non-ilmiah, unscientific, anecdotal) merupakan sumber dokumentasi utama (Na-Nakorn \& Brummet, 2009; Adarsha et al., 2011). Namun demikian, publikasi-publikasi populer tersebut tidak jarang bersifat tidak akurat dan dapat menyebabkan suatu ketidakjelasan. Hal tersebut secara jelas terjadi pada kasus ikan lele dumbo.

Ketidakjelasan identitas ikan lele dumbo terutama adalah ketidakpastian statusnya sebagai spesies murni ikan lele Afrika C. gariepinus ataukah merupakan ikan lele hibrida hasil hibridisasinya dengan spesies ikan lele Taiwan $C$. fuscus. Ikan lele dumbo merupakan ikan lele yang memiliki laju pertumbuhan tinggi dan dapat mencapai ukuran yang besar, sehingga sangat potensial sebagai komoditas perikanan budidaya di Indonesia. Demikian pula, spesies ikan lele Afrika C. gariepinus dengan nama sinonim C. lazera dan C. mossambicus (Teugels, 1984) merupakan spesies ikan lele yang memiliki laju pertumbuhan tinggi, serta dapat mencapai ukuran yang besar dan potensi budidayanya telah dikenal luas di dunia (Na-Nakorn, 1999; Brummet, 2008; NaNakorn \& Brummet, 2009). Kesamaan karakteristik zooteknis tersebut merupakan salah satu penyebab ketidakjelasan identitas ikan lele dumbo, selain belum adanya publikasi ilmiah yang menegaskan identitas ikan lele dumbo.

Tahun introduksi ikan lele dumbo ke Indonesia dalam publikasi-publikasi populer non-ilmiah disampaikan secara berbeda-beda, antara lain disebutkan terjadi pada tahun 1984 (Republik Lele, 2010), tahun 1985 (Sunarma, 2004) ataupun tahun 1986 (Suyanto, 2008). Buku-buku populer menyebutkan bahwa ikan lele dumbo diintroduksi dari Taiwan ke Jakarta oleh PT Cipta Mina Sentosa. Pada awalnya, identitas dalam dokumen pengiriman disebut sebagai spesies ikan lele lokal Taiwan C. fuscus, tetapi selanjutnya direvisi menjadi spesies ikan lele Afrika C. gariepinus. Belakangan, ikan lele tersebut disebut-sebut (termasuk oleh importirnya) sebagai ikan lele hibrida hasil hibridisasi antara betina ikan lele $C$. fuscus dengan jantan ikan lele C. gariepinus (Mahyudin, 2008; Suyanto, 2008). Akhirnya, identitas terakhir tersebutlah yang banyak digunakan dalam buku-buku populer dan dokumen-dokumen resmi yang dikeluarkan oleh pemerintah, sedangkan beberapa peneliti, akademisi, dan praktisi meragukan kebenaran identitas tersebut, dan sebagian meyakini bahwa ikan lele dumbo sebenarnya adalah spesies ikan lele $C$. gariepinus. Dugaan bahwa ikan lele dumbo adalah spesies ikan lele $C$. gariepinus tersebut terutama didasarkan pada karakteristik morfologisnya yang menyerupai morfologi ikan-ikan lele yang belakangan diintroduksi ke Indonesia dan diyakini sebagai spesies ikan lele Afrika C. gariepinus, misalnya ikan lele Belanda yang diintroduksi ke Malang (Jawa Timur) pada tahun 1985-1986, ikan lele Paiton yang diintroduksi ke Paiton, Probolinggo (Jawa Timur) pada tahun 1998, ikan lele Mesir yang diintroduksi ke Cijengkol, Subang (Jawa Barat) pada tahun 2007 maupun ikan lele Masamo yang diintroduksi ke Mojokerto (Jawa Timur) pada tahun 2010 (Sudarto, Maheno Sri Widodo, Pudji Suwargono, Darsono, Fauzul Mubin, pengamatan dan komunikasi pribadi). Beberapa publikasi internasional maupun regional dalam bentuk ulasan (review) tentang perikanan budidaya di Indonesia menuliskan nama ilmiah ikan lele dumbo sebagai C. gariepinus (Eidman, 1989; Yusuf, 1995; Hardjono \& Sunarto, 2005). Namun demikian, seluruh informasi tersebut hanya berdasarkan publikasi-publikasi populer non-ilmiah maupun hasil komunikasi pribadi dengan para ahli dan belum terdapat publikasi yang secara ilmiah menegaskan identitas atau status ikan lele dumbo. Makalah ulasan penelusuran identitas ikan lele dumbo berdasarkan publikasi-publikasi yang relevan ini disusun untuk mendapatkan informasi awal mengenai kejelasan identitas ikan lele dumbo. Hal tersebut perlu untuk diketahui sebagai dasar untuk pelaksanaan penelitian-penelitian lebih lanjut dalam memastikan identitas ikan lele dumbo secara ilmiah.

\section{Penulisan Nama Ilmiah Ikan Lele Dumbo}

Nama latin ikan lele dumbo (termasuk ikan lele sangkuriang) dalam dokumen-dokumen yang dikeluarkan oleh Direktorat Jenderal Perikanan Budidaya maupun Badan Standarisasi Nasional selalu ditulis sebagai (Clarias gariepinus x Clarias fuscus). Berdasarkan tinjauan terhadap beberapa publikasi hasil penelitian berikut ini, maka penulisan tersebut perlu ditinjau ulang. Permasalahan penulisan nama ilmiah tersebut terletak pada urutan posisi penulisan 
nama ilmiah spesies induk tetuanya. Meskipun tata cara penulisan nama ikan hibrida belum diatur oleh Komisi Internasional Tatanama Zoologi (International Commission on Zoological Nomenclature), tetapi secara umum nama ilmiah spesies induk betina ikan hibrida dalam publikasi-publikasi ilmiah ditulis terlebih dahulu (di depan). Oleh karena itu, agar terdapat konsistensi dengan publikasi-publikasi ilmiah, jika ikan lele dumbo memang benar merupakan ikan lele hibrida, maka penulisan nama ilmiah ikan lele dumbo perlu disesuaikan dengan mengikuti cara penulisan nama-nama ikan hibrida dalam publikasi-publikasi ilmiah.

Identitas ikan lele dumbo dalam buku-buku populer disebut-sebut sebagai ikan lele hibrida hasil hibridisasi antara betina ikan lele $C$. fuscus dengan jantan $C$. gariepinus. Demikian pula, hasil penelitian di luar negeri menunjukkan bahwa ikan lele hibrida hasil hibridisasi antara ikan lele $C$. gariepinus dengan ikan lele $C$. fuscus yang karakteristiknya potensial untuk dikembangkan sebagai komoditas perikanan budidaya adalah kombinasi persilangan antara betina ikan lele C. fuscus dengan jantan C. gariepinus (Zheng et al., 1988) atau secara ilmiah ditulis sebagai $C$. fuscus $x$ C. gariepinus dan bukan sebaliknya. Ikan lele hibrida hasil hibridisasi antara betina ikan lele $C$. gariepinus dengan jantan $C$. fuscus (yang secara ilmiah ditulis sebagai $C$. gariepinus x C. fuscus) tidak dilaporkan menunjukkan keragaan yang potensial untuk dikembangkan sebagai ikan budidaya. Hasil penelitian tersebut bersesuaian dengan hasil-hasil hibridisasi spesies ikan lele Afrika C. gariepinus dengan spesies-spesies ikan lele lokal Asia yang lain, yakni dengan ikan lele C. macrocephalus di Thailand (direview oleh Uraiwan, 1993; Na-Nakorn, 1993; 1999; Chinabut \& Kanchanakhan, 2005; Na-Nakorn \& Brummet, 2009), di Vietnam (Minh, 1999; Phan, 2005), serta di Malaysia (direview oleh Kechik, 1995; Abol-Munafi et al., 2006) maupun di Bangladesh dan Myanmar (direview oleh Tripathi, 1996; Thame \& Htwe, 2005), dengan ikan lele C. batrachus di Bangladesh (Rahman et al., 1995; Khan et al., 2000; 2002) dan di India (Sahoo et al., 2003), serta dengan ikan lele C. meladerma di Indonesia (Lenormand et al., 1999) yang juga menunjukkan bahwa ikan lele hibrida hasil hibridisasi antara jantan spesies ikan lele Afrika $C$. gariepinus dengan betina spesies-spesies ikan lele lokal Asia tersebut memiliki keragaan pertumbuhan maupun reproduksi yang lebih potensial sebagai komoditas perikanan budidaya dibandingkan resiproknya. Dengan demikian, kalaupun ikan lele dumbo adalah ikan lele hibrida unggul hasil hibridisasi antara C. fuscus dengan C. gariepinus, maka tentunya merupakan hasil hibridisasi antara betina ikan lele C. fuscus dengan jantan C. gariepinus, sehingga semestinya ditulis sebagai (Clarias fuscus x Clarias gariepinus) dan bukan sebagai (Clarias gariepinus x Clarias fuscus).

\section{Karakterisasi Genetis dan Morfologis Ikan Lele Dumbo}

Ketidakjelasan identitas ikan lele dumbo di Indonesia terutama dikarenakan hingga saat ini belum terdapat publikasi ilmiah hasil penelitian yang secara khusus dan tegas menyebutkan identitasnya, baik secara morfologis (fenotip) maupun genetis (genotip) dibandingkan spesiesspesies induk tetuanya. Aspek-aspek tersebut ke depannya akan menjadi topik penelitian kami.

Publikasi ilmiah tentang karakteristik genetis ikan lele dumbo secara molekuler baru dilaporkan oleh Nuryanto et al. (2012) dengan menggunakan marka RAPD (random amplified polymorphic DNA). Namun demikian, hasil visualisasi fragmen-fragmen (bands) DNA teramplifikasi dalam publikasi tersebut dilaporkan bersifat buram (smear), sehingga tidak ditunjukkan, hanya hasil skor-skornya yang disampaikan. Selain itu, hanya identitas ikan lele sangkuriang yang disampaikan secara jelas, sedangkan identitas ikan-ikan lele yang lain tidak disampaikan secara jelas. Meskipun demikian, berdasarkan narasi yang diberikan, tampaknya yang dimaksud sebagai ikan lele lokal (local catfish) adalah spesies ikan lele lokal $C$. batrachus, sedangkan yang dimaksud dengan ikan lele Afrika (African catfish) adalah ikan lele dumbo yang dalam publikasi tersebut nama ilmiahnya ditulis sebagai $C$. gariepinus. Berdasarkan hasil penelitian Nuryanto et al. (2012), menyimpulkan bahwa ikan lele sangkuriang berkerabat dekat dengan ikan lele Afrika, dan terbukti bahwa ikan lele Afrika adalah induk tetua dari ikan lele sangkuriang. Jika benar bahwa yang dimaksud sebagai ikan lele Afrika dalam publikasi tersebut adalah ikan lele dumbo, maka hasil penelitian tersebut tidak menjawab kejelasan identitas ikan lele dumbo. Kejelasan identitas ikan lele dumbo akan dapat diperoleh jika dilakukan melalui 
perbandingan dengan spesies ikan lele Afrika $C$. gariepinus yang sebenarnya.

Sudarto (1999) dalam ulasannya tentang hasil karakterisasi ikan lele (dan patin) di Indonesia menyatakan bahwa berdasarkan analisis marka DNA mikrosatelit, ikan lele dumbo yang nama ilmiahnya dalam publikasi tersebut disebut sebagai $C$. gariepinus masih merupakan spesies murni dan belum terkontaminasi oleh material genetis spesies lain. Hal tersebut sebenarnya merupakan suatu bukti bahwa ikan lele dumbo adalah spesies ikan lele $C$. gariepinus. Tetapi sayangnya, publikasi tersebut berbentuk ulasan dan bukan merupakan suatu artikel hasil penelitian, sehingga tidak sepenuhnya jelas. Selain itu, asal sampel ikan lele dumbo yang dianalisis juga tidak disebutkan secara jelas. Mengingat pada saat itu selain ikan lele dumbo juga telah terjadi introduksi strain ikan lele Afrika $C$. gariepinus dari Thailand ke Indonesia oleh Charoen Pokphand Group pada tahun 1998 yang selain ditempatkan di Paiton (Jawa Timur), sebagian juga ditempatkan di Pabuaran, Subang (Jawa Barat) yang selanjutnya digunakan dalam kerja sama produksi benih dengan Balai Penelitian Perikanan Air Tawar (BALITKANWAR) Sukamandi (Pudji Suwargono, komunikasi pribadi). Oleh karena itu, penelitian karakterisasi genetis ikan lele dumbo tetap perlu dilakukan untuk memastikan identitasnya.

Penelitian karakterisasi morfologis ikan lele dumbo dibandingkan spesies ikan lele Afrika pernah dilaporkan oleh Hamsyah (2004). Berdasarkan analisis karakteristik morfometrik dan meristiknya dibandingkan dengan ikan lele yang dalam tulisan tersebut disebut sebagai ikan lele Afrika C. gariepinus yang dikoleksi dari BBPBAT Sukabumi (tanpa menyebutkan strainnya), Hamsyah (2004) menyimpulkan bahwa ikan lele dumbo bukan merupakan spesies ikan lele Afrika C. gariepinus, tetapi merupakan ikan lele hibrida hasil hibridisasi antara ikan lele $C$. fuscus dengan $C$. gariepinus. Namun demikian, metode pengukuran (karakterisasi morfometrik dan meristik) dan analisis yang digunakan pada penelitian tersebut bukanlah metode standar karakterisasi morfometrik dan meristik yang secara ilmiah telah terbukti efektif dan banyak digunakan dalam identifikasi spesiesspesies ikan lele (Teugels, 1986; 1992; 1998; Skelton \& Teugels, 1991; Agnese et al., 1997; Rognon et al., 1998; Ng,
1999; 2003a; 2003b; 2003c; 2004; Teugels et al., 1999a; 1999b; 1999c; 2001; Sudarto et al., 2003; 2004; Turan et al., 2005; Ng \& Kottelat, 2008; Hanssen, 2009; Pouyaud et al., 2009; Ng \& Hadiaty, 2011). Selain itu, analisis dan interpretasi data serta kesimpulannya juga tidak jelas. Hasil analisis PCA (principal components analysis) data karakteristik morfometrik pada penelitian tersebut tidak disajikan secara lengkap (koefisien dan skor komponen-komponen utama tidak disajikan), hanya diagram pencar (scatter plot) yang disajikan, yang bahkan diagram pencar tersebut menunjukkan bahwa sebaran sampel ikan lele dumbo dan ikan lele Afrika bersifat saling beririsan (overlap, tidak terpisah), mengindikasikan bahwa sebenarnya karakteristik morfometrik keduanya sulit dibedakan. Selanjutnya, hasil analisis regresi terhadap bagian-bagian badan yang lain dilaporkan bahwa secara umum keduanya memiliki perbedaan, sehingga disimpulkan bahwa kedua ikan lele tersebut berbeda. Namun demikian, metode tersebut tidak pernah digunakan oleh para ahli ikhtiologi untuk mengidentifikasi spesies-spesies ikan lele (lihat metode standar yang digunakan oleh para ahli ikhtiologi tersebut di atas). Lebih lanjut, nilai beberapa karakter morfometrik ikan lele dumbo dan ikan lele Afrika dalam penelitian Hamsyah (2004) tersebut ternyata bersesuaian dengan nilai beberapa karakter morfometrik standar yang umum digunakan dalam identifikasi spesies ikan lele Afrika C. gariepinus (Skelton \& Teugels, 1991; Agnese et al., 1997; Turan et al., 2005; FishBase, 2013a). Dengan demikian, berdasarkan karakter morfometriknya tidak dapat disimpulkan bahwa ikan lele dumbo bukanlah spesies ikan lele Afrika C. gariepinus.

Berdasarkan karakteristik meristiknya, Hamsyah (2004) juga menyatakan bahwa ikan lele dumbo dan ikan lele Afrika tersebut berbeda. Namun demikian, sebenarnya kisaran nilai karakteristik meristik kedua ikan lele tersebut bersesuaian dengan atau masih berada dalam kisaran nilai karakteristik meristik spesies ikan lele Afrika C. gariepinus yang dilaporkan oleh para ahli ikhtiologi (Teugels, 1986; 1992; Skelton \& Teugels, 1991; Agnese et al., 1997; Cabuy et al., 1999; Fapohunda \& Godstates, 2007; Teugels et al., 2007; Hanssens, 2009; Wiecaszek et al., 2010; FishBase, 2013a). Analisis karakteristik meristik yang dilakukan oleh Hamsyah (2004) terutama berkaitan dengan asimetri 
(abnormalitas) kedua ikan lele tersebut melalui penghitungan karakter meristik pada sisi badan sebelah kiri dan kanan, sebagaimana yang juga dilakukan oleh Nurhidayat (2000) pada ikan lele dumbo dari tiga daerah sentra budidaya ikan lele di Pulau Jawa. Padahal, penghitungan karakter meristik pada bagian badan yang berpasangan yang dilakukan oleh para ahli ikhtiologi dalam mengidentifikasi spesies ikan lele sedapat mungkin hanya dilakukan pada sisi badan sebelah kiri (Ng, 1999; 2003a; 2003b; 2003c; 2004; Ng \& Kottelat, 2008; Ng \& Hadiaty, 2011). Hal-hal tersebut menunjukkan bahwa kesimpulan yang diberikan oleh Hamsyah (2004) yang menyatakan bahwa karakteristik meristik ikan lele dumbo berbeda dari ikan lele Afrika $C$. gariepinus tidaklah tepat. Dengan demikian, penelitian karakterisasi morfologis (biometrik) ikan lele dumbo tetap perlu dilakukan untuk memastikan identitasnya.

\section{Publikasi-Publikasi Pendukung Identitas Ikan Lele Dumbo}

Meskipun tidak secara langsung dapat menjelaskan identitas ikan lele dumbo, beberapa publikasi berikut ini memberikan bukti-bukti atau indikasi-indikasi bahwa tampaknya ikan lele dumbo bukanlah ikan lele hibrida hasil hibridisasi antara ikan lele $C$. fuscus dengan $C$. gariepinus, tetapi lebih merupakan spesies ikan lele Afrika $C$. gariepinus. Namun demikian, untuk memperkuat indikasi-indikasi tersebut tetap perlu dilakukan penelitian-penelitian lebih lanjut yang secara langsung menggunakan sampel ikan lele dumbo.

Lenormand et al. (1999) dalam penelitian hibridisasi antara ikan lele lokal C. batrachus, C. meladerma, C. nieuhofii, dan C. teijsmanni dengan spesies ikan lele Afrika juga menggunakan nama ilmiah $C$. gariepinus untuk spesies ikan lele Afrika yang dikoleksinya dari Sukamandi. Kepastian identitas ikan lele tersebut telah diverifikasi berdasarkan metode standar karakterisasi biometrik spesies ikan lele (Teugels, 1986) dan menunjukkan bahwa ikan lele tersebut adalah spesies ikan lele Afrika C. gariepinus. Ikan lele yang digunakan tersebut tentunya adalah ikan lele dumbo, karena pada saat pelaksanaan penelitian tersebut (tahun 1997) belum terjadi introduksi ikan lele ke Indonesia, selain ikan lele dumbo dan ikan lele Afrika C. gariepinus yang diintroduksi dari Belanda yang secara terbatas hanya digunakan untuk keperluan penelitian di Universitas Brawijaya, Malang (NaNakorn \& Brummet, 2009; FAO, 2013; FishBase, 2013b). Hal tersebut merupakan suatu bukti indikasi bahwa ikan lele dumbo merupakan spesies ikan lele Afrika C. gariepinus.

Publikasi-publikasi populer di Indonesia menyebutkan bahwa ikan lele dumbo diintroduksi melalui atau dari Taiwan. Istilah "melalui" (via) atau "dari” tersebut tampaknya tidak sepenuhnya jelas. Hal tersebut dapat ditelusuri sebagai berikut:

Data DIAS (Database on Introduction of Aquatic Species) di FAO (Food and Agriculture Organization) dan FishBase menyebutkan bahwa pada tahun 1985 telah terjadi introduksi spesies ikan lele Afrika C. gariepinus ke Indonesia dari Belanda dan Afrika Selatan dan tidak tercatat pernah adanya introduksi ikan lele dari Taiwan (Na-Nakorn \& Brummet, 2009; FAO, 2013; FishBase, 2013b). Jika benar bahwa ikan lele dumbo yang diintroduksi pada tahun 1985 merupakan spesies ikan lele Afrika C. gariepinus, maka secara internasional diakui bahwa introduksinya bukan dari Taiwan. Sebaliknya, jika benar bahwa ikan lele dumbo diintroduksi dari Taiwan, maka bisa jadi ikan lele dumbo bukanlah spesies ikan lele Afrika C. gariepinus sehingga secara internasional introduksinya tidak dicatat dalam data introduksi spesies ikan lele Afrika C. gariepinus. Namun demikian, hal tersebut tampaknya kecil kemungkinannya, mengingat data di FAO dan FishBase juga tidak mencatat adanya translokasi (introduksi) ikan lele hibrida hasil persilangan antara ikan lele C. fuscus dengan C. gariepinus. Introduksi ikan lele Afrika $C$. gariepinus ke Indonesia pada tahun-tahun berikutnya juga tidak tercatat di FAO maupun FishBase. Hal tersebut menunjukkan bahwa introduksi ikan lele dumbo maupun ikan-ikan lele Afrika C. gariepinus di Indonesia belum terdokumentasi dengan akurat dan benar, sehingga wajar jika dapat menyebabkan suatu ketidakjelasan.

Liao \& Liu (1989); Liao et al. (1993; 2001); dan Liao (2000) dalam publikasi-publikasi internasional berbentuk ulasan tentang perikanan budidaya di Taiwan tidak pernah menyebutkan adanya introduksi spesies ikan lele Afrika $C$. gariepinus ke Taiwan (padahal introduksi spesies-spesies ikan yang lain disebutkan) maupun kegiatan budidaya, serta hibridisasinya dengan ikan lele $C$. fuscus. Spesies ikan lele yang dilaporkan pernah diintroduksi adalah $C$. batrachus dari Thailand pada tahun 1972 dan telah disilangkan dengan ikan 
lele C. fuscus. Berdasarkan sifat biologisnya yang dilaporkan memiliki laju pertumbuhan yang tinggi dan dapat mencapai ukuran yang besar, maka terdapat kemungkinan juga bahwa spesies ikan lele yang disebut sebagai $C$. batrachus tersebut sebenarnya adalah ikan lele Afrika C. gariepinus, dan mungkin terjadi kesalahan identifikasi. Namun demikian, hal tersebut belum dapat dipastikan, karena data di FAO dan FishBase menyebutkan bahwa ikan lele Afrika C. gariepinus baru diintroduksi ke Thailand dari Laos pada tahun 1987 (FAO, 2013; FishBase, 2013b), sehingga tampaknya juga terdapat ketidakjelasan tentang identitas spesies-spesies ikan lele di Taiwan. Hal tersebut terutama dikarenakan belum adanya publikasi ilmiah tentang karakteristik morfologis ikan lele hibrida C. fuscus x C. gariepinus dari Taiwan. Data di FAO dan FishBase juga tidak mencatat adanya introduksi ikan lele Afrika C. gariepinus ke Taiwan, tetapi mencatat bahwa pada tahun 1985 telah terjadi translokasi ikan lele Afrika C. gariepinus dari Taiwan ke Filipina (FAO, 2013; FishBase, 2013b). Berdasarkan informasi-informasi tersebut dapat diduga bahwa ikan lele Afrika C. gariepinus tidak pernah diintroduksi ke Taiwan, atau kalaupun benar pernah diintroduksi dan disilangkan dengan ikan lele $C$. fuscus di Taiwan, tetapi kegiatan budidayanya tidak mengalami perkembangan yang nyata, sehingga belum pernah tercatat dalam publikasi-publikasi ulasan internasional dari Taiwan. Hal tersebut juga dapat dilihat dari publikasipublikasi internasional dalam bentuk ulasan tentang biologi dan budidaya ikan lele yang tidak menyebutkan adanya kegiatan perikanan budidaya dengan menggunakan ikan lele hasil hibridisasi antara ikan lele $C$. fuscus dengan C. gariepinus di Taiwan (Bartley et al., 1997; 2001; Na-Nakorn \& Brummet, 2009). Hanya ikan lele hasil hibridisasi antara betina ikan lele C. macrocephalus dengan jantan C. gariepinus di Thailand yang telah mencapai tahap komersialisasi produksi (Na-Nakorn, 1999; Bartley et al., 1997; 2001; 2009; Na-Nakorn \& Brummet, 2009).

Salah satu informasi utama yang mengindikasikan bahwa ikan lele dumbo bukan ikan lele hibrida hasil hibridisasi antara betina ikan lele $C$. fuscus dengan jantan $C$. gariepinus adalah pada aspek biologi reproduksinya. Hasil penelitian Wu et al. (1990) dalam analisis morfologi dan karyologi ikan lele hibrida hasil hibridisasi antara betina ikan lele C. fuscus dengan jantan C. gariepinus di Cina menunjukkan bahwa karakter reproduksi jantan ikan lele hibrida tersebut bersifat tidak fertil (sterile). Artinya, jantan ikan lele hibrida tersebut tidak dapat melangsungkan proses reproduksi atau tidak dapat menghasilkan keturunan. Karakteristik biologi reproduksi jantan ikan lele hibrida hasil hibridisasi antara betina ikan lele $C$. fuscus dengan jantan $C$. gariepinus yang bersifat tidak fertil tersebut berbeda dari karakteristik biologi reproduksi jantan ikan lele dumbo yang bersifat normal, yakni bersifat fertil dan dapat melangsungkan proses reproduksi, serta menghasilkan keturunan (generasigenerasi berikutnya). Demikian pula, ikan lele hibrida hasil hibridisasi antara betina ikan lele $C$. macrocephalus dengan jantan C. gariepinus di Thailand (Na-Nakorn, 1993) dan di Malaysia (Abol-Munafi et al., 2006) maupun ikan lele hibrida hasil hibridisasi antara betina ikan lele $C$. meladerma dengan jantan C. gariepinus di Indonesia (Lenormand et al., 1999) yang juga memiliki keragaan unggul sebagai ikan budidaya, jantan-jantannya juga dilaporkan bersifat tidak fertil atau tidak dapat digunakan untuk menghasilkan keturunan. Ikan lele hibrida hasil hibridisasi antara betina ikan lele C. batrachus dengan jantan C. gariepinus di Bangladesh yang juga potensial sebagai ikan budidaya, jantannya juga dilaporkan cenderung bersifat tidak fertil (Khan et al., 2000). Ikan lele hibrida hasil hibridisasi antara betina ikan lele $C$. macrocephalus dengan jantan C. gariepinus kadang-kadang juga disebut sebagai ikan lele dumbo, tetapi ikan lele hibrida tersebut tentu bukanlah ikan lele dumbo, karena hibridisasi tersebut dilaporkan baru dilakukan di Thailand pada tahun 1990 (Na-Nakorn, 1993; 1999; Uraiwan, 1993). Hasil-hasil penelitian tentang cenderung tidak fertilnya jantan ikan-ikan lele hibrida hasil hibridisasi antara jantan ikan lele Afrika $C$. gariepinus dengan betina spesies-spesies ikan lele lokal Asia tersebut mengindikasikan bahwa ikan lele dumbo bukanlah ikan lele hibrida hasil hibridisasi antara betina ikan lele $C$. fuscus dengan jantan $C$. gariepinus, karena karakteristik biologi reproduksi jantan ikan lele dumbo bersifat fertil dan normal. Selain itu, perkawinan di antara sesama ikan lele dumbo yang dilakukan oleh para pembudidaya pada kenyataannya menghasilkan keturunan dengan karakteristik yang serupa dengan induk-induknya (pengamatan pribadi). Jika ikan lele dumbo merupakan ikan lele hibrida hasil hibridisasi antara ikan lele C. fuscus 
dengan $C$. gariepinus, maka perkawinan di antara sesama ikan lele dumbo tersebut seharusnya menghasilkan keturunan dengan karakteristik yang berbeda dari ikan lele dumbo. Perkawinan di antara sesama ikan hibrida akan menghasilkan keturunan dengan karakteristik yang tidak stabil dan berbeda-beda (Perez \& Rylander, 1998). Hal tersebut juga merupakan indikasi bahwa ikan lele dumbo bukanlah ikan lele hibrida.

\section{KESIMPULAN}

Berdasarkan tinjauan terhadap beberapa publikasi dalam ulasan ini, terindikasi bahwa ikan lele dumbo bukanlah ikan lele hibrida hasil hibridisasi antara betina ikan lele C. fuscus dengan jantan C. gariepinus, tetapi tampaknya lebih merupakan spesies ikan lele Afrika $C$. gariepinus. Untuk memastikan hal tersebut perlu dilakukan penelitian-penelitian karakterisasi genetis dan morfologis menggunakan sampel ikan lele dumbo dibandingkan dengan spesies ikan lele Afrika C. gariepinus.

\section{DAFTAR ACUAN}

Abol-Munafi, A.B., Liem, P.T., Ambak, M.A., \& Siraj, S.S. 2006. Effects of maturational hormone treatment on spermatogenesis of hybrid catfish (Clarias macrocephalus x C. gariepinus). Journal of Sustainability Science and Management, 1(1): 24-31.

Adarsha, H.S., Prabhudeva, K.N., \& Rajanna, K.B. 2011. A review on translocation and management of genetic resources of commercially important aquaculture finfishes. Universal Journal of Environmental Research and Technology, 1(2): 115-123.

Agnese, J.F., Teugels, G.G., Galbusera, P., Guyomard, R., \& Volckaert, F. 1997. Morphometric and genetic characterization of sympatric populations of Clarias gariepinus and $C$. anguillaris from Senegal. Journal of Fish Biology, 50: 1,143-1,157.

Bartley, D.M., Crespi, V., Fleischer, I.J., \& Subasinghe, R. 2005. Aquatic alien species and their contribution to aquatic production, food security, and poverty alleviation: an overview of data from ASEAN countries. In The Way Forward: Building capacity to combat impacts of aquatic invasive alien species and associated transboundary pathogens in ASEAN countries. Final report of the regional workshop hosted by the Department of Fisheries, Government of Malaysia, 12-16 July 2004. Network of Aquaculture Centres in Asia-Pacific. Bangkok, Thailand, p. 127-144.

Bartley, D.M., Nguyen, T.T.T., Halwart, M., \& De Silva, S.S. 2009. Use and exchange of aquatic genetic resources in aquaculture: information relevant to access and benefit sharing. Reviews in Aquaculture, 1: 157-162. (Editorial).

Bartley, D.M., Rana, K., \& Immink, A.J. 1997. The use of inter-species hybrids in aquaculture and their reporting to FAO. FAO Aquaculture Newsletter No. 17 - December 1997. Inland Water Resources and Aquaculture Service, Fisheries Department, Food and Agriculture Organization (FAO). Rome. p. 7-13. www. fao.org (diakses pada tanggal 19 November 2009).

Bartley, D.M., Rana, K., \& Immink, A.J. 2001. The use of inter-specific hybrids in aquaculture and fisheries. Reviews in Fish Biology and Fisheries, 10: 325-337.

Brummet, R.E. 2008. Clarias catfish: biology, ecology, distribution and biodiversity. in Ponzoni, R.W. \& Nguyen, N.H. (Eds.), Proceeding of a Workshop on the Development of a Genetic Improvement Program for African Catfish Clarias gariepinus. Accra, Ghana, 5-9 November 2007. WorldFish Center. Penang, Malaysia, p. 64-72.

Cabuy, E., Adriaens, D., Verraes, W., \& Teugels, G.G. 1999. Comparative study on the cranial morphology of Gymnallabes typus (Siluriformes: Clariidae) and their less anguilliform relatives, Clariallabes melas and Clarias gariepinus. Journal of Morphology, 240: 169-194.

Chinabut, S. \& Kanchanakan, S. 2005. The Country Papers: Thailand. In The Way Forward: Building capacity to combat impacts of aquatic invasive alien species and associated transboundary pathogens in ASEAN countries. Final report of the regional workshop hosted by the Department of Fisheries, Government of Malaysia, 12-16 July 2004. Network of Aquaculture Centres in Asia-Pacific. Bangkok, Thailand, p. 343346.

Eidman, H.M. 1989. Exotic aquatic species introduction 
into Indonesia. In De Silva, S.S. (Ed.) Exotic Aquatic Organisms in Asia. Proceeding of the Workshop on Introduction of Exotic Aquatic Organisms in Asia. Asian Fisheries Society Special Publication No. 3. Asian Fisheries Society. Manila, Philippines, p. 57-62.

FAO. 2013. Database on Introduction of Aquatic Species. Diakses pada tanggal 1 Juni 2013 dari: http://www. fao.org/fishery/introsp/search/en

Fapohunda, O.O. \& Godstates, R. 2007. Biometry and composition of fish species in Owena Reservoir, Ondo State, Nigeria. Journal of Central European Agriculture, 8(1): 99-104.

Ferraris, C.J. 2007. Checklist of catfishes, recent, and fossil (Osteichthyes: Siluriformes), and catalogue of siluriform primary types. Zootaxa 1418. Magnolia Press. Auckland, New Zealand, 628 pp.

FishBase. 2013a. Morphology data of Clarias gariepinus. Diakses pada tanggal 1 Juni 2013 dari: http://fishbase. org/physiology/MorphDataSummary.php?genusna $\mathrm{me}=$ Clarias\&speciesname $=$ gariepinus\&autoctr $=1$ 499

FishBase. 2013b. Introduction of Clarias gariepinus. Diakses pada tanggal 1 Juni 2013 dari: http://www. fishbase.org/Introductions/IntroductionsList.php?I $\mathrm{D}=1934 \&$ GenusName $=$ Clarias $\&$ SpeciesName $=$ gar iepinus\&f $=139 \&$ StockCode $=2130$

Hamsyah, I. 2004. Perbedaan karakteristik antara ikan lele dumbo dan lele Afrika (Clarias gariepinus Burchell). Skripsi. Program Studi Teknologi dan Manajemen Akuakultur, Departemen Budidaya Perairan, Fakultas Perikanan dan Ilmu Kelautan, Institut Pertanian Bogor. Bogor, 54 hlm.

Hanssens, M. 2009. A review of the Clarias species (Pisces; Siluriformes) from the Lower Congo and the Pool Malebo. Journal of Afrotropical Zoology, 5: 27-40.

Hardjono \& Sunarto, A. 2005. The Country Papers: Indonesia. In: The Way Forward: Building capacity to combat impacts of aquatic invasive alien species and associated transboundary pathogens in ASEAN countries. Final report of the regional workshop hosted by the Department of Fisheries, Government of Malaysia, 12-16 July 2004. Network of Aquaculture Centres in Asia-Pacific. Bangkok, Thailand, p. 260-283.
Kechik, I.A. 1995. Aquaculture in Malaysia. In Bagarinao, T.U. \& Flores, E.E.C. (Eds.) Towards Sustainable Aquaculture in Southeast Asia and Japan. ADSEA '94 Proceeding. SEAFDEC Aquaculture Department. Iloilo, Philippines, p. 125-135.

Khan, M.M.R., Cleveland, A., \& Mollah, M.F.A. 2002. A comparative study of morphology between F1 hybrid magur and their parents. Online Journal of Biological Sciences, 2(10): 699-702.

Khan, M.M.R., Mollah, M.F.A., \& Ahmed, G.U. 2000. Mass production of hybrid magur and its culture potential in Bangladesh. Aquaculture Research, 31: 467-472.

Knud-Hansen, C.F., Batterson, T.R., McNabb, C.D., Hadiroseyani, Y., Dana, D., \& Eidman, H.M. 1989. Hatchery techniques for egg and fry production of Clarias batrachus (Linnaeus). Aquaculture, 89: 9-19.

Lenormand, S., Slembrouck, J., Pouyaud, L., Subagja, J., \& Legendre, M. 1999. Evaluation of hybridisation in five Clarias species (Siluriformes, Clariidae) of African (C. gariepinus) and Asian origin (C. batrachus, C. meladerma, C. nieuhofii, and C. teijsmanni). In Legendre, M. \& Parisele, A. (Eds.), The Biological Diversity and Aquaculture of Clariid and Pangasiid Catfishes in South-East Asia. Proceeding of The Mid-Term Workshop of the Catfish Asia Project, Cantho, 11-15 May 1998. Vietnam, p. 195-209.

Liao, I.C. 2000. The state of finfish diversification in Asian aquaculture. Cahiers Options Mediterraneennes, 47: 109125.

Liao, I.C., Su, H.M., \& Chang, E.Y. 1993. A review of genetic research and conservation issues in Taiwan. In Main, K.L. \& Reynolds, E. (Eds.) Selective Breeding of Fishes in Asia and United States. Proceeding of a Workshop in Honolulu, 3-7 May 1993. Hawaii, p. 162-180.

Liao, I.C., Su, H.M., \& Chang, E.Y. 2001. Techniques in finfish larviculture in Taiwan. Aquaculture, 200: 1-31.

Liao, I.C. \& Liu, H.C. 1989. Exotic aquatic species in Taiwan. in De Silva, S.S. (Ed.), Exotic Aquatic Organisms in Asia. Proceeding of the Workshop on Introduction of Exotic Aquatic Organisms in Asia. Asian Fisheries Society Special Publication No. 3. Asian Fisheries Society. Manila, Philippines, p. 101-111.

Mayhudin, K. 2008. Panduan lengkap agribisnis lele. Penebar Swadaya. Jakarta, $170 \mathrm{hlm}$. 
Minh, L.T. 1999. Preliminary results on growth and body composition in Clarias macrocephalus, Clarias gariepinus and their hybrid (C. macrocephalus female x C. gariepinus male). In Legendre, M. \& Parisele, A. (Eds.), The Biological Diversity and Aquaculture of Clariid and Pangasiid Catfishes in South-East Asia. Proceeding of The Mid-Term Workshop of the Catfish Asia Project. Cantho, 11-15 May 1998. Vietnam, p. 211-215.

Na-Nakorn, U. 1993. Review of aquaculture genetic researches in Thailand. Biotropia, 6: 45-54.

Na-Nakorn, U. 1999. Genetic factors in fish production: a case study of the catfish Clarias. In Mustafa, S. (Ed.) Genetics in Sustainable Fisheries Managament. Fishing News Books. London, p. 175-187.

Na-Nakorn, U. \& Brummet, R.E. 2009. Use and exchange of aquatic genetic resources for food and aquaculture: Clarias catfish. Reviews in Aquaculture, 1: 214-223.

$\mathrm{Ng}$, H.H. 1999. Two new species of catfishes of the genus Clarias from Borneo (Teleostei: Clariidae). The Raffles Bulletin of Zoology, 47(1): 17-32.

$\mathrm{Ng}$, H.H. 2003a. Clarias microstomus, a new species of clariid catfish from eastern Borneo (Teleostei: Siluriformes). Zoological Studies, 40(2): 158-162.

Ng, H.H. 2003b. Clarias sulcatus, a new walking catfish (Teleostei: Clariidae) from Pulau Redang. Ichthyological Exploration of Freshwaters, 15(4): 289-294.

Ng, H.H. 2003c. Clarias nigricans, a new species of clariid catfish (Teleostei: Siluriformes) from eastern Borneo. The Raffles Bulletin of Zoology, 51(2): 393-398.

$\mathrm{Ng}$, H.H. 2004. Clarias insolitus, a new species of clariid catfish (Teleostei: Siluriformes) from southern Borneo. Zootaxa, 284: 1-8.

Ng, H.H. \& Hadiaty, R.K. 2011. Clarias microspilus, a new walking catfish (Teleostei: Clariidae) from northern Sumatra, Indonesia. Journal of Threatened Taxa, 3(3): $1,577-1,584$.

Ng, H.H. \& Kottelat, M. 2008. The identity of Clarias batrachus (Linnaeus, 1758) with designation of a neotype (Teleostei: Clariidae). Zoological Journal of Linnean Society, 153: 725-732.

Nurhidayat, M.A. 2000. Fluktuasi asimetri dan abnormalitas pada ikan lele Dumbo (Clarias sp.) yang berasal dari tiga daerah sentra budidaya di Pulau Jawa. Tesis. Program Pascasarjana. Institut Pertanian Bogor. Bogor, 26 hlm. Nuryanto, A., Rahayu, D.R.U., \& Sukmaningrum, S. 2012. Molecular identification and phylogenetic relationship among local, Sangkuriang, and African catfish based on RAPD marker. Biotropia, 19(1): 42-50.

Perez, J.E. \& Rylander, M.K. 1998. Hybridization and its effect on species richness in natural habitats. Intercencia, 23(3): 137-139.

Phan, T.V. 2005. The Country Papers: Vietnam. In The Way Forward: Building capacity to combat impacts of aquatic invasive alien species and associated transboundary pathogens in ASEAN countries. Final report of the regional workshop hosted by the Department of Fisheries, Government of Malaysia, 12-16 July 2004. Network of Aquaculture Centres in Asia-Pacific. Bangkok, Thailand, p. 346-352.

Pouyaud, L., Sudarto, \& Paradis, E. 2009. The phylogenetic structure of habitat shift and morphological convergence in Asian Clarias (Teleostei, Siluriformes: Clariidae). Journal of Zoological Systematics and Evolutionary Research, 47(4): 344-356.

Rahman, M.A., Bhadra, A., Begum, N., Islam, M.S., \& Hussain, M.G. 1995. Production of hybrid vigor through cross breeding between Clarias batrachus Lin. and Clarias gariepinus Bur. Aquaculture, 138: 125-130.

Republik Lele. 2010. Republik lele bukan fiksi. Diakses pada tanggal 1 Juni 2013 dari: http://republiklele.blogspot. com/2010/09/republik-lele-bukan-fiksi.html

Sahoo, S.K., Giri, S.S., Sahu, A.K., \& Ayyappan, S. 2003. Experimental hybridization between catfish Clarias batrachus (Linn.) x Clarias gariepinus (Bur.) and performance of the offspring in rearing operations. Asian Fisheries Science, 16: 157-166.

Skelton, P.H. \& Teugels, G.G. 1991. A review of the clariid catfishes (Siluroidei, Clariidae) occuring in southern Africa. Revista de Hydrobiologia Tropical, 24(3): 241260.

Sudarto. 1993. A review of of the fish breeding research and practices in Indonesia. In Main, K.L.\& Reynolds, E. (Eds.), Selective Breeding of Fishes in Asia and United States. Proceeding of a Workshop in Honolulu, 3-7 May 1993. Hawaii, p. 182-189. 
Sudarto. 1999. Karakterisasi genetik dan zooteknik ikan lele (Clariidae) dan patin (Pangasiidae) dari wilayah Asia Tenggara. Makalah dalam Hardjamulia, A., Sumantadinata, K., Sugama, K., Sudradjat, A., \& Heruwati, E.S. (penyunting). Prosiding Seminar Hasil Penelitian Genetika Ikan. 8 Februari 1999. Jakarta, hlm. 26-29.

Sudarto. 2003. Description of two new Clarias species from Borneo (Siluriformes, Clariidae). Cybium, 27(2): 153-161.

Sudarto. 2004. Description of a new clariid catfish, Clarias pseudonieuhofii from west Borneo (Siluriformes: Clariidae). Zoological Studies, 43(1): 8-19.

Sunarma, A. 2004. Peningkatan produktivitas usaha lele Sangkuriang (Clarias sp.). Makalah disampaikan pada Temu Unit Pelaksana Teknis (UPT) dan Temu Usaha Direktorat Jenderal Perikanan Budidaya. Departemen Kelautan dan Perikanan. 4-7 Oktober 2004. Bandung, 13 hlm.

Suyanto, S.R. 2008. Budi daya ikan lele (edisi revisi). Penebar Swadaya. Jakarta, $92 \mathrm{hlm}$.

Teugels, G.G. 1984. The nomenclature of African Clarias used in aquaculture. Aquaculture, 38: 373-374. (Technical Note).

Teugels, G.G. 1986. A systematic revision of the African species of the genus Clarias (Pisces: Clariidae). Annales Musee Royal de l'Afrique Centrale, 247: 1-199.

Teugels, G.G. 1992. Clariidae. In Leveque, C., Paugy, D., \& Teugles, G.G. (Eds.). The Fresh and Brackish Water Fishes of West Africa Volume 2. ORSTOM-MRAC. Paris. p. 468495.

Teugels, G.G. 1998. Intra- and interspecific morphometric variation in Clarias gariepinus and $C$. anguillaris (Siluroidei, Clariidae). In Agnese, J.F. (Ed.) Genetics and Aquaculture in Africa. Actes du colloque Génétique et aquaculture en Afrique, Abidjan, $1^{\text {er }}$ - 4 avril 1997. Institut Francais de Recherche Scientifique pour le Developpement en Cooperation. Paris, France, p. 241-248.

Teugels, G.G. 2003. Clarias lamottei (Silurifoems, Clariidae), a natural intergeneric hybrid from west Africa. Cybium, 27(1): 11-15.
Teugels, G.G., Adriaens, D., Devaere, S., \& Musschoot, T. 2007. Clariidae. In Stiassny, M.L.J., Teugels, G.G., \& Hopkins, C.D. (Eds.) The Fresh and Brackish Water Fishes of Lower Guinea, West-Central Africa Volume I. IRD-MNHN-MRAC. Paris, p. 653-691.

Teugels, G.G., Legendre, M., \& Hung, L.T. 1999a. Preliminary results on the morphological characterisation of natural population and cultured strains of Clarias species (Siluriformes, Clariidae) from Vietnam. In Legendre, M. \& Parisele, A. (Eds.) The Biological Diversity and Aquaculture of Clariid and Pangasiid Catfishes in South-East Asia. Proceeding of The Mid-Term Workshop of the Catfish Asia Project. Cantho, 11-15 May 1998. Vietnam, p. 27-30.

Teugels, G.G., Diego, R.C., Pouyaud, L., \& Legendre, M. 1999b. Redescription of Clarias macrocephalus (Siluriformes: Clariidae) from South-East Asia. Cybium, 23(3): 285-295.

Teugels, G.G., Gustiano, R., Diego, R., Legendre, M., \& Sudarto. 1999c. Preliminary results on the morphological characterisation of natural population and cultured strains of Clarias species (Siluriformes, Clariidae) from Vietnam. In Legendre, M. \& Parisele, A. (Eds.) The biological diversity and aquaculture of Clariid and Pangasiid catfishes in South-East Asia. Proceeding of The Mid-Term Workshop of the Catfish Asia Project, Cantho, 11-15 May 1998. Vietnam, p. 31-36.

Teugels, G.G., Sudarto, \& Pouyaud, L. 2001.Description of a new Clarias species from Southeast Asia based on morphological and genetical evidence (Siluriformes, Clariidae). Cybium, 25(1): 81-92.

Thame, M. \& Htwe, M.M. 2005. The country papers: Myanmar. In The way forward: Building capacity to combat impacts of aquatic invasive alien species and associated transboundary pathogens in ASEAN countries. Final report of the regional workshop hosted by the Department of Fisheries, Government of Malaysia, 12-16 July 2004. Network of Aquaculture Centres in Asia-Pacific. Bangkok, Thailand, p. 308315. 
Tripathi, S.D. 1996. Present status of breeding and culture of catfishes in South Asia. Aquatic Living Resources, 9: 219-228.

Turan, C., Yalcin, S., Turan, F., Okur, E., \& Akyurt, I. 2005. Morphometric comparisons of African catfish, Clarias gariepinus, in Turkey. Foolia Zoologica, 54(1-2): 165172.

Uraiwan, S. 1993. A review of fish breeding programs and conservation issues in Thailand. In Main, K.L. \& Reynolds, E. (Eds.), Selective breeding of fishes in Asia and United States. Proceeding of a Workshop in Honolulu, 3-7 May 1993. Hawaii, p. 198-204.

Van Weerd, J.H. 1995. Nutrition and growth in Clarias species - a review. Aquatic Living Resources, 8: 395401.

Wiecaszek, B., Krzykawski, S., Antoszek, A., Kosik, J., \& Serwotka, P. 2010. Morphometric characteristics of the juvenile of north African catfish Clarias gariepinus (Burchell, 1822) from the heated water aquaculture.
Electronic Journal of Polish Agricultural Universities, 13(2). url: http://www.ejpau.media.pl/volume13/issue2/ art-02.html

Wu, G.M., Luo, J.R., Chen, K.C., Xian, C.B., Lin, G.G., Wang, Z.X., Lin, Z.P., Luo, J.L., \& Pan, K.Q. 1990. Analysis and comparison of morphology and cytology between the F1 hybrid catfish (Clarias fuscus x C. lazera) and its parents. Acta Hydrobiologica Sinica, 14(4): 328-335. (in Chinese with English abstract).

Yusuf, D. 1995. Aquaculture in Indonesia. In Bagarinao, T.U. \& Flores, E.E.C. (Eds.), Towards Sustainable Aquaculture in Southeast Asia and Japan. ADSEA '94 Proceeding SEAFDEC Aquaculture Department. Iloilo, Philippines, p. 109-115.

Zheng, W.B., Pan, J.H., \& Liu, W.S. 1988. Culture of catfish in China. Aquaculture, 75: 35-44.

Zonneveld, N., Rustidja, Viveen, W.J.A.R., \& Mudana, W. 1988. Induced spawning and egg incubation of the Asian catfish, Clarias batrachus. Aquaculture, 74: 41-47. 
